Law \& Economics Working Papers

Law \& Economics Working Papers Archive:

2003-2009

University of Michigan Law School

Year 2009

\title{
The Supreme Court's Impact on Securities Class Actions: An Empirical Assessment of Tellabs
}

\author{
Adam C. Pritchard* $\quad$ Stephen Choi ${ }^{\dagger}$
}

*University of Michigan Law School, acplaw@umich.edu

${ }^{\dagger}$ NYU Law School, stephen.choi@nyu.edu

This paper is posted at University of Michigan Law School Scholarship Repository.

http://repository.law.umich.edu/law_econ_archive/art107 
The Supreme Court's Impact on Securities Class Actions: An Empirical Assessment of Tellabs

\author{
Stephen J. Choi \\ New York University \\ Law School \\ New York, NY 10012 \\ (212) 992-8962 \\ stephen.choi@nyu.edu \\ A.C. Pritchard \\ University of Michigan \\ Law School \\ Ann Arbor, MI 48109 \\ (734) 647-4048 \\ acplaw@umich.edu \\ Draft \#9 \\ 17 August 2009
}




\section{Supreme Court and Securities Class Actions}

\section{The Supreme Court's Impact on Securities Class Actions: \\ An Empirical Assessment of Tellabs}

The Supreme Court is not all that interested in securities law; on average, it hears about one securities case per year. ${ }^{1}$ The Court's inattention means that many areas of securities regulation are left to be developed by the lower courts and the SEC. In the field of securities class actions, that means mainly development by the district and appellate courts, with occasional amicus participation from the SEC. In recent years, however, the Supreme Court has taken a more active role in the area, loading up its still small securities docket with securities class actions. The impetus for this attention no doubt arises from the enactment of the Private Securities Litigation Reform Act of 1995 (PSLRA), which gave rise to a host of interpretive questions.

In this paper, we assess the impact of the Supreme Court's recent securities decisions on the lower courts, where most of the action in securities fraud class actions occurs. In particular, we are interested in the effect of Tellabs, Inc. v. Makor Issues \& Rights, Ltd.,$~^{2}$ on lower court decisions. Tellabs interprets the PSLRA's "strong inference" standard for pleading scienter-the defendants' state of mind-in Rule $10 \mathrm{~b}-5$ cases; $^{3}$ the Supreme Court reversed a very lenient Seventh Circuit decision for drawing inferences with respect to scienter, but replaced it with a standard that is nonetheless relatively generous to plaintiffs.

Tellabs represents one of the Supreme Court's first opportunities to interpret the

\footnotetext{
${ }^{1}$ A.C. Pritchard, Justice Lewis F. Powell, Jr. and the Counter-Revolution in the Federal Securities Laws, 52 Duke L.J. 841 (2003).

2551 U.S. 308 (2007).

${ }^{3}$ Exchange Act $\S 21 \mathrm{D}(\mathrm{b})(2)$.
} 


\section{Supreme Court and Securities Class Actions}

PSLRA. ${ }^{4}$ More importantly, Tellabs addressed a question central to motion to dismiss practice

in the lower courts. The PSLRA makes the motion to dismiss the main event in securities fraud class actions, effectively making district courts gatekeepers charged with screening out meritless class actions at an early stage. The evidence on how effective district courts are at doing this task is mixed, ${ }^{5}$ but there can be little doubt that Tellabs will influence lower court judges as they undertake this sorting process. The strong inference scienter provision interpreted in Tellabs is central to Congress's efforts to screen out meritless class actions in enacting the PSLRA, and appellate courts have split in determining the height of the barrier it has created for plaintiffs pleading fraud. ${ }^{6}$ Thus, Tellabs has the potential to affect significantly motion to dismiss outcomes.

To assess this possibility, we collect a sample of securities class action complaints filed from 2003 until the date of the Tellabs decision in 2007, along with the decisions resolving motions to dismiss in those cases. We limit our sample to suits filed just prior to the Tellabs decision to avoid possible selection effects from Tellabs on suits filed after the decision, allowing us to observe directly the impact of Tellabs on motion to dismiss decisions. Although

\footnotetext{
${ }^{4}$ An earlier case, Dura Pharmaceuticals, Inc. v. Broudo, 544 U.S. 336 (2005), addresses the question of the plaintiffs' burden - for both pleading and proof - with respect to loss causation in Rule 10b-5 cases, that is, the required connection between the defendant's misrepresentation and the plaintiffs' losses. We touch upon Dura briefly below.

The Supreme Court interpreted the PSLRA again recently in Stoneridge Investment Partners LLC v. Scientific-Atlanta, Inc., 128 S.Ct. 761 (2008). This decision is likely to have significant implications for secondary defendants, but it was handed down after our sample period, so we leave it for future work.

${ }^{5}$ Stephen J. Choi, Do the Merits Matter Less After the Private Securities Litigation Reform Act? 23 J. of Law, Economics \& Organization 598 (2007); Stephen J. Choi, Stephen J., Karen K. Nelson \& A.C. Pritchard, The Screening Effect of the Private Securities Litigation Reform Act, 6 J. Empirical Leg. Stud. 35 (2009); Marilyn F. Johnson, Karen K. Nelson \& A. C. Pritchard, Do the Merits Matter More? The Impact of the Private Securities Litigation Reform Act, $23 \mathrm{~J}$. of Law, Economics \& Organization 627 (2007).

${ }^{6}$ See Joseph A. Grundfest and A.C. Pritchard, Statutes with Multiple Personality Disorders: The Value of Ambiguity in Statutory Design and Interpretation, 54 Stan. L. Rev. 627 (2002) (describing Congress's tacit "agreement to disagree" over the PSLRA's pleading standard and the ensuing split in the circuits over the interpretation of that standard).
} 


\section{Supreme Court and Securities Class Actions}

we collect data from all circuits, we highlight in our analysis the Ninth Circuit, traditionally the leading venues for securities fraud class actions. The Ninth Circuit also has the most stringent standard for pleading scienter. We find that Tellabs correlates with a significantly lower dismissal rate in the Ninth Circuit. A lower rate of dismissals may improve on shareholder welfare if the suits that are not dismissed consist primarily of meritorious suits. However, we also find that suits that settled in the post-Tellabs period correspond with a higher incidence of nuisance settlements-suggesting that Tellabs undermined the anti-frivolous litigation objective of the PSLRA. We conclude that Tellabs was a significant victory for the plaintiffs' bar.

We proceed as follows. Part 1 describes the Tellabs decision and develops hypotheses relating to the effect of those decisions in the different circuits. Part 2 describes the sample and provides descriptive statistics. Part 3 presents the results of our empirical tests of our hypotheses. Part 4 concludes.

\section{Background and Hypotheses}

Tellabs addressed the key provision in the PSLRA for weeding out frivolous "stock price drop" lawsuits: the strong inference standard for scienter. That provision requires plaintiffs to "state with particularity facts giving rise to a strong inference that the defendant acted with the required state of mind." 7 The provision was modeled after the standard applied in the Second Circuit prior to the PSLRA, which was generally regarded as the most stringent at the time. ${ }^{8}$ In

\footnotetext{
${ }^{7}$ Exchange Act $\S 21 \mathrm{D}(\mathrm{b})(2), 15$ U.S.C. 78u-4(b)(2).

${ }^{8}$ See S. Rep. No. 104-98, at 15 (1993), reprinted in 1995-96 U.S.C.C.A.N. 679, 694.
} 


\section{Supreme Court and Securities Class Actions}

adopting the strong inference provision, Congress specifically rejected the looser standard applied in the Ninth Circuit. ${ }^{9}$

Prior to the PSLRA, the Second Circuit had held that plaintiffs could meet the scienter standard in one of two ways. First, plaintiffs could plead that the defendants had the motive to commit fraud and the opportunity to do so. ${ }^{10}$ Although simplistic allegations of motive that could apply generally, such as keeping one's job, ${ }^{11}$ were insufficient to meet the standard, other allegations of specific financial gain from a transaction were sufficient to state a claim. ${ }^{12}$ Second, plaintiffs could meet the standard with circumstantial evidence of either recklessness or conscious behavior. ${ }^{13}$ Generally, this standard required plaintiffs to plead contemporaneous facts, conditions, or statements to show that the defendants knew or should have known that the alleged misstatement was misleading when made. ${ }^{14}$

After the PSLRA was enacted, the Second Circuit relied on the legislative history and held that the PSLRA codified its pre-PSLRA pleading approach. ${ }^{15}$ By contrast, the Ninth Circuit

\footnotetext{
${ }^{9}$ Consistent with the language of Rule 9(b), before the PSLRA, the Ninth Circuit had developed a heightened pleading standard allowing plaintiffs to plead scienter generally, but demanding particularity in alleging all other elements of securities fraud. See In re Glenfed Sec. Litig., 42 F.3d 1541 ( $9^{\text {th }}$ Cir. 1994).

${ }^{10}$ Goldman v. Belden, 754 F.2d 1059 (2d Cir. 1985).

${ }^{11}$ See In re Crystal Brands Sec. Litig., 862 F. Supp. 745, 749 (D. Conn. 1994).

${ }^{12}$ See Goldman v. Belden, 754 F.2d 1059, 1070 (2d Cir. 1985) (holding that allegations that defendants bullish statements to market were connected to significant stock sales met motive and opportunity test).

${ }^{13}$ See San Leandro Emergency Med. Group Profit Sharing Plan v. Philip Morris Co., 75 F.3d 801 (2d Cir. 1996) (requiring plaintiffs seeking to meet recklessness standard to provide higher level of detail than that required under motive and opportunity test).

${ }^{14}$ See Shields v. Citytrust Bancorp, 25 F.3d 1124, 1129 (2d. Cir. 1994) (rejecting allegations of fraud where plaintiffs failed to contrast public disclosure with contemporaneous internal document or data).

${ }^{15}$ Novak v. Kasaks, 216 F.3d 300, 311 (2000). The Second Circuit has, however, refined its explication of the standard post-PSLRA. Now, rather than a two-prong test, the Second Circuit has set forth a list of the general types of allegations that will meet the heightened pleading standard for scienter. Synthesizing its own case law on the pleading standard, the Second Circuit held that plaintiffs can plead a strong inference of fraudulent intent by including sufficient allegations that the defendants: received concrete, personal benefits from the alleged fraud; participated in deliberately illegal behavior; knew or had access to facts "suggesting" that the public statements were inaccurate; or "failed to check information they had a duty to monitor." See id. at 311. This refined standard, of course, still leaves room for pleading based on motive and opportunity.
} 


\section{Supreme Court and Securities Class Actions}

recognized that the PSLRA repudiated that court's old standard, which did not require that state of mind be pleaded with specificity. In interpreting the "strong inference" provision, the Ninth Circuit also relied on the PSLRA's legislative history, but concluded that the statute raised the standard above that of the Second Circuit. ${ }^{16}$ Under this higher pleading standard, the Ninth Circuit rejected allegations based on motive and opportunity and on recklessness. Instead, to meet the Ninth Circuit's new pleading standard for scienter, plaintiffs had to plead, "at a minimum, particular facts giving rise to a strong inference of deliberate or conscious recklessness." ${ }^{17}$ Most circuits, however, took a middle course in interpreting the strong inference standard, concluding that motive and opportunity allegations might suffice to support a strong inference of scienter, but courts would need to evaluate such allegations on a "caseby-case" basis. ${ }^{18}$

The choice of scienter standard has important consequences: the Ninth Circuit, in adopting the most stringent standard post-PSLRA, also substantially increased its dismissal rate. In an earlier study, Pritchard and Sale found that Ninth Circuit courts dismissed cases at a $63 \%$ rate, while Second Circuit courts dismissed only $36 \%{ }^{19}$

When the Supreme Court finally entered the fray over the interpretation of the strong inference standard in Tellabs, however, it did not resolve this longstanding split among the

\footnotetext{
${ }^{16}$ See In re Silicon Graphics Inc. Sec. Litig., 183 F.3d 970, 974 (9th Cir. 1999).

${ }^{17}$ Id.

${ }^{18}$ Greebel v. FTP Software, Inc., 194 F.3d 185 (1st Cir. 1999); Ottman v. Hanger Orthopedic Group, Inc. 353 F.3d 338 (4th Cir. 2003); Nathenson v. Zonagen, Inc., 267 F.3d 400 (5th Cir. 2001); In re Comshare, Inc. Sec. Litig., 183 F.3d 542 (6th Cir. 1999); Makor Issues \& Rights, Ltd. v. Tellabs, Inc., 437 F.3d 588 (7th Cir. 2006); Fla. State Bd. of Admin v. GreenTree Fin. Corp., 270 F.3d 645 (8th Cir. 2001); In re Silicon Graphics, 183 F.3d 970 (9th Cir. 1999); City of Philadelphia v. Fleming Cos., 264 F.3d 1245 (10th Cir. 2001); Bryant v. Avado Brands, Inc., 187 F.3d 1271 (11th Cir. 1999).

${ }^{19}$ A.C. Pritchard and Hillary A. Sale, What Counts as Fraud? An Empirical Study of Motions to Dismiss Under the Private Securities Litigation Reform Act, 2 Journal of Empirical Legal Studies 125 (2005).
} 


\section{Supreme Court and Securities Class Actions}

circuits over the stringency of the standard. Instead, it addressed a collateral, but related, issue: In considering whether the facts alleged by the plaintiff gave rise to strong inference of scienter, should a court consider competing inferences arising from those facts? The occasion for considering the question arose from the Seventh Circuit's decision in Makor Issues \& Rights, Ltd. v. Tellabs, Inc. holding that a complaint should survive "if it alleges facts from which, if true, a reasonable person could infer that the defendant acted with the required intent" (Reasonableness). ${ }^{20}$ In so holding, the Seventh Circuit specifically rejected the position of the Sixth Circuit, which had held that "plaintiffs are entitled only to the most plausible of competing inferences" (Preponderance). ${ }^{21}$

The Supreme Court in Tellabs split the difference, steering a middle course between the Seventh Circuit's position and the position urged by the defendants and the government, which both endorsed the Sixth Circuit's requirement that the plaintiff's complaint establish scienter by a preponderance. ${ }^{22}$ As the government's brief pointed out, the Seventh Circuit's standard would have made Congress's effort in enacting the scienter standard toothless, as it would mean reverting to pre-PSLRA standards under Rule $9(b)$ of the Federal Rules of Civil Procedure. ${ }^{23}$ Justice Ginsberg, writing for the majority in Tellabs, rejected that reasonableness standard, instead requiring a comparative inquiry: "A complaint will survive, we hold, only if a reasonable person would deem the inference of scienter cogent and at least as compelling as

\footnotetext{
${ }^{20} 437$ F.3d 588, (7th Cir. 2006).

${ }^{21}$ Id. at 601-602 (quoting Fidel v. Farley, 392 F.3d 220, 227 (6th Cir. 2004)).

22 Brief for the United States as Amicus Curiae Supporting Petitioners, Tellabs, Inc. v. Makor Issues \& Rights, Ltd., No. 06-484, 2007 WL 460606, at *26 (arguing that "if the alleged facts give rise to two seemingly equally strong competing inferences, a court must conclude that the inference of scienter is not itself strong.") (citations and quotation marks omitted).

${ }^{23}$ Id. at *23 (arguing that "the court of appeals' standard appears to be equivalent to the standard that it (and some other courts of appeals) had applied before the enactment of the Reform Act, under which a complaint was sufficient if the plaintiff pleaded facts that supported at least a reasonable inference of state of mind.").
} 


\section{Supreme Court and Securities Class Actions}

any opposing inference one could draw from the facts alleged." ${ }^{24}$ Ties go to the plaintiff, but the plaintiff, as the master of the complaint, must show that the inference of fraudulent intent is at least as likely as an innocent one (Equal Inference). Justices Scalia and Alito would have gone further, requiring plaintiffs to show fraudulent intent by a preponderance of the evidence. $^{25}$ Justice Stevens urged the adoption of a more generous "probable cause" standard. $^{26}$

The Seventh Circuit's Tellabs decision was an outlier. Most circuit courts had anticipated the Supreme Court's ruling that the inference must be at least equally plausible to be a "strong inference," 27 although several had adopted the preponderance standard urged by the government and adopted by Scalia and Alito in their concurrences. ${ }^{28}$ Only the Third Circuit had adopted the "reasonable" standard of the Seventh Circuit. ${ }^{29}$ Consequently, the Supreme Court's decision in Tellabs, while repudiating the lenient standard adopted in the Seventh Circuit, arguably had a more significant effect in the circuits that had adopted the "preponderance" standard: the First, Fourth, Sixth, and Ninth Circuits. We posit three hypotheses on the effect of Tellabs on the Circuits.

H1A: Ninth Circuit and other courts previously applying the preponderance standard will be less likely to dismiss complaints based on scienter grounds post-Tellabs.

H1B: Courts applying the equality standard should be no more likely to dismiss complaints based on scienter grounds post-Tellabs.

\footnotetext{
${ }^{24}$ Tellabs, 127 S.Ct. at 2510.

${ }^{25}$ Id. at 2513 (Scalia, J., concurring); id. at 2515 (Alito, J., concurring).

${ }^{26}$ Id. at 2516 (Steven, J., dissenting).

${ }^{27}$ Acito v. IMCERA Group, Inc., 47 F.3d 47 (2d Cir. 1995); Rosenzweig v. Azurix Corp., 332 F.3d 854 (5th Cir. 2003); Fla. State Bd. Of Admin v. Gree Tree Fin. Corp., 270 F.3d 645 (8th Cir. 2001); Pirraglia v. Novell, Inc., 339 F.3d 1182 (10th Cir. 2003); Garfield v. NDC Health Corp., 466 F.3d 1255 (11th Cir. 2006).

${ }^{28}$ In re Credit Suiss First Boston Corp., 431 F.3d 36 (1st Cir. 2005); Ottman v. Hanger Orthopedic Group, Inc., 353 F.3d 338 (4th Cir. 2003); Helwig v. Vencor, Inc., 251 F.3d 540 (6th Cir. 2001); Gompper v. VISX, Inc., 298 F.3d 893 (9th Cir. 2002).

${ }^{29}$ In re Suprema Specialties, Inc. Sec. Litig., 438 F.3d 256 (3rd Cir. 2006).
} 


\section{Supreme Court and Securities Class Actions}

H1C: Courts previously applying the reasonableness standard should be more likely to dismiss complaints based on scienter grounds post-Tellabs.

We are also interested in the consequences for defendants stemming from the relatively generous Tellabs equality standard. We predict that defendants will be less likely to get an early dismissal of weak complaints with prejudice. To state it differently, district courts applying the equality standard will be more likely to give plaintiffs an opportunity to amend defective complaints before final dismissal.

H2A: Ninth Circuit and other courts previously applying the preponderance standard will take longer to dismiss complaints with prejudice post-Tellabs.

H2B: Courts applying the equality standard should take no more decisions to dismiss complaints with prejudice post-Tellabs.

H2C: Courts previously applying the reasonableness standard should dismiss complaints with prejudice sooner post-Tellabs.

We now turn to the effect of the Supreme Court's decision on monetary outcomes. The next proposition follows directly from the last two: if defendants find it more difficult to obtain a dismissal with prejudice, or if it takes longer to obtain that dismissal, they will be more willing to settle even weak cases in order to avoid the costs of litigation.

H3A: Defendants in Ninth Circuit and other courts previously applying the preponderance standard will be more likely to pay nuisance settlements post-Tellabs.

H3B: Defendants in courts applying the equality standard should be no more likely to pay nuisance settlements post-Tellabs.

H3C: Defendants in courts previously applying the reasonableness standard should be more likely to pay nuisance settlements post-Tellabs.

\section{Sample and Descriptive Statistics}

\subsection{Sample}

To test our hypotheses, we construct our sample by collecting complaints from securities class actions filed from 2003 to mid-2007 (right before the Tellabs decision on June 


\section{Supreme Court and Securities Class Actions}

$21,2007)$ from the Stanford Securities Clearinghouse. Thus, all of the cases in our sample were filed pre-Tellabs, but many of the decisions resolving motions to dismiss those cases were handed down after Tellabs. The strength of our data set is that this time period minimizes any selection effects that follow from the Tellabs decision. We are able to observe directly the impact of Tellabs on the motion to dismiss decision without having to take into account any shift in the mix of cases appearing before the court. It, however, precludes us in this study from testing how plaintiffs' attorneys responded to Tellabs in their decision to file suit.

We limit our sample to cases in which an allegation of fraud was made under Rule $10 \mathrm{~b}-5$ of the Securities Exchange Act of 1934, although we include public offering cases ( $\S 11$ of the Securities Act) and proxy cases ( $\S 14$ of the Exchange Act) if a Rule $10 \mathrm{~b}-5$ claim is made as well. We exclude cases in which financial firms (SIC 6000 to 6999) are the primary defendant because of the different regulatory regime that applies to them.

[Insert Table 1 About Here].

Table 1 shows that the lawsuit filings were distributed relatively equally across our sample period, although there is some tapering off in 2006. Looking at the frequency of lawsuit by circuit, we find that the Second and Ninth Circuits are clearly head-and-shoulders above their peers with $18 \%$ and $27 \%$ of the lawsuits. Thus, nearly half of the cases in our sample come from these two circuits, which sit on opposite ends of the scale for pleading scienter.

Looking at suit outcomes, we see that settlement is the most common outcome $(47 \%$ of the cases), but dismissal with prejudice is not far behind (40\%). If dismissal with prejudice is combined with voluntary dismissal, over half of the cases end up being dismissed in some manner. This finding suggests that plaintiffs' lawyers are taking on substantial risk in these 


\section{Supreme Court and Securities Class Actions}

cases, although that risk may not be evenly distributed across all cases. Notably, only a trivial percentage of cases are resolved through summary judgment or trial. These findings confirm that the motion to dismiss is the main event for most defendants; if they fail to prevail at this point, settlement is likely. Comparing the Ninth Circuit with the other circuits, we see that settlement is slightly less likely in the Ninth Circuit.

\subsection{Control Variables}

Descriptive statistics regarding the cases are presented in Table 2. We use the following set of variables in each of our multivariate models as controls (collectively referred as "Case Controls"). From the complaints, we collect information about the causes of action alleged and use indicator variables for the cause of action. ${ }^{30}$ All of our cases were selected to include a Rule 10b- 5 cause of action (the base category). Eleven percent of the cases also allege a $\S 11$ claim under the Securities Act of 1933 (Section 11). Section 11 is only available for material misstatements and certain omissions in the registration statement used in a public offering, but it allows for substantial easier because it does not require plaintiffs to plead fraudulent intent. Moreover, loss causation and due diligence are affirmative defenses. Claims under $\S 14$ of the Exchange Act relating to misstatements in a proxy statement also carry an easier standard for state of mind and loss causation (Section 14), but these are found in a much smaller percentage of the sample. Most suits allege solely Rule $10 \mathrm{~b}-5$ violations.

[Insert Table 2 About Here].

\footnotetext{
${ }^{30}$ For each class action, we collected data from the last filed consolidated class complaint. When a consolidated complaint was not available, we collected data from the last filed complaint on file with the Stanford Securities Class Clearinghouse.
} 


\section{Supreme Court and Securities Class Actions}

Complaints will typically provide detail on the revelation for the fraud that triggered the lawsuit. We include in our Case Controls indicator variables for government investigations (Govt. Investigation) and financial restatements (Restatement), each a high profile adverse event, are the most common events giving rise to these suits. The presence of a government investigation or a financial restatement indicates a higher likelihood of wrongdoing and thus a stronger case for the plaintiffs. The overall strength of the case will also be bolstered if the firm has terminated a top officer (Officer Term.) or its auditor (Auditor Term.) due to events relating to the fraud in question.

We also include variables in our Case Controls relating to the firm-specific characteristics of the defendant issuer. We include a measure of firm size, measured as market value of equity measured at the end of the fiscal year preceding the beginning of the class period (Market Capitalization). Larger firms may have greater resources to defend against a class action. On the other hand, larger firms may also a greater ability to pay a settlement, leading to more vigorous prosecution of case by plaintiffs' attorneys. We also include two industry controls that may relate to case strength and loss causation. Firms in the high technology sector (High Tech) may have stock prices that are particularly vulnerable to declines in sales or earnings. Firms in pharmaceuticals and medical devices (FDA) may experience steep stock price declines if the Food and Drug Administration deny approval of their new products.

We also collect data for our Case Controls relating to the use of confidential witnesses in the complaints in our sample (Confidential). This data is collected from the first complaint after the selection of the lead plaintiff. Since the cases were all selected prior to the Tellabs decision, we are unable to test the impact of Tellabs on confidential witness use. Nonetheless, this data 


\section{Supreme Court and Securities Class Actions}

may offer insights on the quality of the complaints filed in the different circuits. We see that complaints filed in the Ninth Circuit are somewhat less likely to rely on confidential witnesses, but the difference is not significant at conventional levels ( $p$-value=0.134).

For our tests focusing on dismissals based on a lack of scienter, we include a set of variables relating to the allegation of defendant motive in the complaint (referred to as the "Motive Variables"). We collect allegations from the complaint relating to motive for the fraud and the triggering event for its revelation. Motive allegations are typically intended to help satisfy the scienter requirement. Insider trading is by far the most common motivation alleged (Insider Trading). Other motive allegations that may lead an issuer to overinflate their financials or overvalue their shares refer to executive bonus compensation (Bonus) and the intention of the issuer to offer securities (Offering), to use their stock as consideration for acquisitions (Acquisition), or to merge with another company in a stock merger (Merger).

Lastly, we track variables relating to the lead plaintiffs and their attorneys. This data ${ }^{31}$ only tracks lead plaintiffs and their selected lead counsel. As a result, the data exists only for securities class actions where the litigation reached the lead plaintiff and lead counsel stage. Because we lack data on the lead plaintiff and selected lead counsel for all our cases, we use these variables only for robustness tests. We include an indicator variable for the presence of only institutions as lead plaintiff (All Institutional Lead Plaintiff). Institutional lead plaintiffs may have greater ability in monitoring plaintiffs' attorneys and bring only stronger cases. We also include an indicator variable for the most experienced securities class action firms that act as

\footnotetext{
${ }^{31}$ These data are obtained from Stephen J. Choi, Motions for Lead Plaintiff in Securities Class Actions, Working Paper, NYU (2009).
} 


\section{Supreme Court and Securities Class Actions}

lead counsel (Top Attorney). ${ }^{32}$ Attorneys more experienced in class actions may have different selection criteria for the cases that they bring or may have greater resources to bring to bear in investigating fraud and drafting complaints. These differences may affect probability of dismissal.

Table 3 presents descriptive statistics relating to the rationale for dismissing the complaint. Scienter, the issue addressed by Tellabs, is far and away the most commonly invoked argument for dismissing complaints, with $40 \%$ of dismissals relying at least in part on the failure to adequately allege scienter. The same argument is rejected in nearly a quarter of dismissal decisions.

[Insert Table 3 About Here].

\section{Empirical Testing}

\subsection{Suit Outcome and Tellabs}

We begin by assessing the effect of Tellabs on case outcomes, specifically, the likelihood of dismissal. As noted above, scienter is by far the most frequently litigated issue in motions to dismiss, appearing in over $60 \%$ of motion to dismiss decisions, so Tellabs certainly has the potential to influence outcomes. On the other hand, the Reasonableness standard adopted by the Seventh Circuit was an outlier, with most circuits adhering to either the Equal Inference standard adopted the Supreme Court in Tellabs or the Preponderance standard espoused by Justices Scalia and Alito in their concurrences. And as Justice Scalia noted in his concurrence, the difference between the equal inference and preponderance standards is likely to be

\footnotetext{
32 See Stephen J. Choi, Motions for Lead Plaintiff in Securities Class Actions, Working Paper, New York University
} (2009). 


\section{Supreme Court and Securities Class Actions}

determinative in only a small fraction of cases. ${ }^{33}$ Given the limited change to the law effected by Tellabs in most circuits, would it make any difference to outcomes?

We begin to assess that question by looking at dismissals. We estimate a logit model using as our dependent variable Terminate, a binary division between defendant wins summary judgment, dismissal with prejudice, or voluntary dismissal - and plaintiff victories settlement or trial verdict. We construct variables capturing both the standard for drawing inferences used in the circuits prior to Tellabs. Our base category for drawing inferences is the Equal Inference standard ultimately adopted by the Supreme Court, so we include indicator variables for the Reasonableness standard adopted by the Seventh Circuit in Tellabs (also used in the Third Circuit), and Preponderance is the standard advocated by Justices Scalia and Alito (adopted in the First, Fourth, Sixth, and Ninth Circuits). We use these variables, along with the Post-Tellabs variable and interaction variables for each. We also include the Case Control variables.

$$
\begin{aligned}
& \text { Terminate }_{i}=\alpha+ß_{1 i} \text { Post-Tellabs }_{i}+\beta_{2 i} \text { Reasonableness }_{i} \\
& + \text { ß3iReasonableness * Post-Tellabs } s_{i}+\beta_{4 i} \text { Preponderance }_{i} \\
& +\beta_{5 \mathrm{i}} \text { Preponderance }{ }^{*} \text { Post-Tellabs } s_{\mathrm{i}}+\sum \beta_{\mathrm{ki}} \text { Case Controls } \mathrm{si}_{\mathrm{k}}+\varepsilon_{\mathrm{i}}
\end{aligned}
$$

Table 4 reports the results as Model 1. In order to assess the impact of Tellabs on the Ninth Circuit, we run one model with just cases from that circuit, eliminating the Reasonableness and Preponderance circuit related variables (Model 2). In our last model, we estimate the model for the entire sample replacing the Reasonableness and Preponderance circuit related variables

\footnotetext{
${ }^{33}$ Tellabs, $127 \mathrm{~S}$. Ct. at 2514 ("I doubt that in this instance what I deem to be the correct test will produce results much different from the Court's. How often is it that inferences are precisely in equipoise?").
} 


\section{Supreme Court and Securities Class Actions}

with an indicator variable for the Ninth Circuit and an interaction term for Ninth Circuit x PostTellabs (Model 3).

The results in Table 4 confirm that Tellabs made dismissal significantly less likely, with our key variable of interest, Post-Tellabs, negative and significant in all three models. The indicator variables for Reasonableness and Preponderance are insignificant, however, as are the interaction variables in Model 1 . The coefficients on Ninth Circuit and Ninth Circuit x PostTellabs are also not significant in Model 3. Thus, Tellabs appears to have had an impact on overall dismissals, but it cannot be isolated based on the law in those circuits prior to the Supreme Court's decision. ${ }^{34}$

Most of the Case Controls in Table 4 are not significantly different from zero. The coefficient on Restatement is negative and significant in all three models, indicating that a restatement makes it less likely that a case will terminate. Larger firms, as measured by market capitalization, on the other hand, seem to be more successful in obtaining a termination of litigation. The coefficient on $\ln$ (market capitalization) is positive and significant at the $1 \%$ level in Models 1 and 3.

[Table 4 about here]

\subsection{Scienter as Grounds for Dismissal and Tellabs}

The regression results presented in Table 4 focused on the overall effect of Tellabs on case outcomes. We now focus on final dismissal decisions based on scienter. In place of the Terminate dependent variable used in the last set of regressions, we instead use an ordered

\footnotetext{
${ }^{34}$ As a robustness test, we added the Top Attorney and All Institutional Lead Plaintiff variables to assess the importance of attorney and lead plaintiff expertise (and selection) to the three models in Table 4. Unreported, neither variable is significant in the models. Moreover, the robustness models generate the same qualitative results as in Table 4.
} 


\section{Supreme Court and Securities Class Actions}

logit model, with the dependent variable "Scienter." Scienter is defined to equal 1 if the final motion to dismiss decision ordered dismissal (at least partially) based on a failure to plead scienter with particularity, 0 if the decision both denied and granted dismissal based on scienter, and -1 if the decision denied dismissal based on scienter. We estimate the same three models in Table 4, including the same Case Controls. To each model, we add the Motive Variables for the scienter alleged in the complaint (Insider Trading, Bonus, Offering, Acquisition, and Merger).

$$
\begin{aligned}
& \text { Scienter }_{i}=\alpha+\beta_{1 i} \text { Post-Tellabs }_{i}+\beta_{2 i} \text { Reasonableness }_{i} \\
& +\beta_{3 i R e a s o n a b l e n e s s} \text { * Post-Tellabs } s_{i}+\beta_{4 i} \text { Preponderance }_{i} \\
& +\beta_{5 \mathrm{i}} \text { Preponderance }^{*} \text { Post-Tellabs } \mathrm{i}_{\mathrm{i}}+\sum \beta_{\mathrm{ki}} \text { Case Controls } \mathrm{s}_{\mathrm{ki}} \\
& +\sum \beta_{\mid i} \text { Motive Variables }{ }_{l i}+\varepsilon_{i}
\end{aligned}
$$

We present the results in Table 5. These results show that impact of Tellabs is primarily in the circuits that had previously applied the Preponderance standard. Those circuits were significantly more likely to dismiss prior to Tellabs, with a positive coefficient on the Preponderance variable that is significant at the $5 \%$ level in Model 1 . The interaction variable is negative and significant at the $10 \%$ level (and the sum of Post-Tellabs and Post-Tellabs $\mathrm{x}$ Preponderance is negative and significant at the $1 \%$ level), suggesting that those circuits became less likely to dismiss after Tellabs. This evidence would seem to contradict Justice Scalia's suggestion in his dissent that the difference between the Equal Inference standard and Preponderance standard was unlikely to come into play in most cases. None of the Motive Variables were significant in the models.

[Table 5 About Here] 


\section{Supreme Court and Securities Class Actions}

As expected, we find that the Ninth Circuit is more likely to dismiss based on scienter grounds than other circuits. Tellabs, however, seems to have diminished the Ninth Circuit's propensity to dismiss. Post-Tellabs is negative and significant at the $5 \%$ level in the regression for the Ninth Circuit sub-sample (Model 2), and the interaction variable for the Ninth Circuit and Post-Tellabs is significant in the overall sample (Model 3). Thus, Tellabs appears to have had its most substantial effect reducing the propensity of circuits to dismiss on scienter grounds in circuits previously applying the Preponderance standard, and in particular, the Ninth Circuit. $^{35}$

\subsection{Litigation Delay and Tellabs}

We now turn to the cost of Tellabs for defendants seeking dismissal. As our proxy for those costs, we assess the effect of Tellabs on the time required for defendants to obtain a dismissal with prejudice.

One important question for litigants is how many "bites at the apple" will be afforded to the plaintiffs. Defendants are anxious to obtain a dismissal with prejudice at the earliest moment to minimize the expense and distraction of the lawsuit. Plaintiffs, however, want to avail themselves of the opportunity to craft a complaint that will pass muster with the district court; earlier opinions dismissing a complaint without prejudice may provide guidance to the

\footnotetext{
${ }^{35}$ As a robustness test, we added the Top Attorney and All Institutional Lead Plaintiff variables to assess the importance of attorney and lead plaintiff expertise (and selection) to the three models in Table 5. Unreported, neither variable is significant in the models. Moreover, the results of the robustness models differ somewhat from those in Table 5. While the coefficient on Preponderance is still positive, it is now significant at the $1 \%$ level. In contrast, the coefficient on the interaction term Post-Tellabs $x$ Preponderance is not significantly different from zero. Similarly, the coefficient on Post-Tellabs for the Ninth Circuit-only subset is not significantly different from zero. Lastly, while the coefficient on Ninth Circuit in the model with all the circuits is still positive and significant at the $1 \%$ level, the coefficient on Ninth Circuit x Post-Tellabs is not significantly different from zero. Nonetheless, the robustness results suffer from a possible selection issue-data on the lead plaintiff and lead counsel exist only for cases that survive to the lead plaintiff selection stage of litigation.
} 


\section{Supreme Court and Securities Class Actions}

plaintiffs on what they need to do to craft an adequate complaint. Judges may vary in their willingness to afford plaintiffs that opportunity, and they have fairly substantial discretion in dismissing with or without prejudice, at least after the first dismissal, which will typically be without prejudice.

Tellabs may have sent an important signal to judges with respect to how lenient they should be in affording plaintiffs an opportunity to plead. And for courts that previously adhered to the Preponderance standard, Tellabs announced a more lenient standard that might well require a re-evaluation of the complaint if it had not already been dismissed with prejudice. For courts adhering to the reasonableness standard, Tellabs invites a new inquiry applying its more exacting standard. To test these propositions, we limit our sample to those cases that ended up with a dismissal with prejudice. We use the number of dismissal decisions before a court reaches the final dismissal with prejudice as a proxy for the length of the dismissal decision. For those cases that resulted in a dismissal with prejudice, the number of dismissal decisions ranged from 1 to 4 in our data set. We use an ordered logit model, with the number of decisions required to get to a dismissal with prejudice as our dependent variable. We estimate three models with the same independent variables (including Case Controls and Motive Variables) as in the Scienter models in Table 5. 


\section{Supreme Court and Securities Class Actions}

$$
\begin{aligned}
& \text { Dismissal Decisions }=\alpha+\beta_{1 i} \text { Post-Tellabs } s_{i}+\beta_{2 i} \text { Reasonableness } s_{i}
\end{aligned}
$$

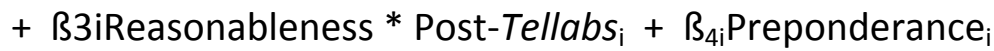

$$
\begin{aligned}
& +\beta_{5 i} \text { Preponderance * Post-Tellabs } s_{\mathrm{i}}+\sum \beta_{\mathrm{ki}} \text { Case Controls } \mathrm{s}_{\mathrm{k}} \\
& +\sum ß_{\mid i} M \text { Motive Variables }{ }_{\mid i}+\varepsilon_{\mathrm{i}}
\end{aligned}
$$

We present our results in Table 6 . The most interesting results are from the regressions examining the Ninth Circuit. The coefficient on Post-Tellabs in the Ninth Circuitonly subset regression (Model 2) is positive and significant at the $1 \%$ level, indicating that it took significantly more dismissal motion decisions to reach the final dismissal with prejudice after Tellabs. In Model 3 (with all the circuits), the coefficient on Ninth Circuit is positive and significant at the $1 \%$ level. The coefficient on Ninth Circuit $\times$ Post-Tellabs is positive and significant at the $5 \%$ level. The Ninth Circuit - which appears to be the most willing to grant dismissal even prior to Tellabs - takes considerably longer to do it after the Tellabs decision. ${ }^{36}$

The results from Table 6 indicate that the Ninth Circuit's greater willingness to dismiss was apparently tempered, to some extent, by providing plaintiffs with every opportunity to meet the pleading standard. That tendency was only accentuated by Tellabs, with the PostTellabs coefficient strongly significant in the regression for the Ninth Circuit subsample and the interaction variable significant in the overall sample.

\section{[Insert Table 6 about here]}

We have found that Tellabs reduced the likelihood of dismissal on scienter grounds in the Ninth Circuit, while at the same time requiring defendants to go through more rounds of

\footnotetext{
${ }^{36}$ As a robustness test, we added the Top Attorney and All Institutional Lead Plaintiff variables to assess the importance of attorney and lead plaintiff expertise (and selection) to the three models in Table 6. Unreported, the robustness models generate the same qualitative results as in Table 6 .
} 


\section{Supreme Court and Securities Class Actions}

motions to dismiss in order to obtain a final dismissal with prejudice. Both of these consequences mean greater litigation costs for defendants, suggesting that defendants should be more willing to pay a settlement in order to rid themselves of even a weak case. Thus, another measure of the overall effect of Tellabs on litigation outcomes is the incidence of nuisance settlement.

In Table 7, we focus on the sub-sample of class actions that resulted in a settlement. We use as our dependent variable "Nuisance," which equals 1 if the settlement amount was for $\$ 3$ million or less and 0 if the settlement amount was for greater than $\$ 3$ million. Did Tellabs increase the incidence of nuisance settlement? We estimate logit regressions with Nuisance as the dependent variable. We estimate three models with the same the same independent variables (including Case Controls) as in the Terminate models in Table 4.

$$
\begin{aligned}
& \text { Nuisance }=\alpha+\beta_{1 i} \text { Post-Tellabs }_{\mathrm{i}}+\beta_{2 i} \text { Reasonableness } s_{\mathrm{i}} \\
& +\beta_{3 i R e a s o n a b l e n e s s} * \text { Post-Tellabs }_{i}+\beta_{4 i} \text { Preponderance }_{i} \\
& +\beta_{5 \mathrm{i}} \text { Preponderance * Post-Tellabs }{ }_{\mathrm{i}}+\sum \beta_{\mathrm{ki}} \text { Case Controls } \mathrm{si}_{\mathrm{ki}}+\varepsilon_{\mathrm{i}}
\end{aligned}
$$

For the overall sample, we find that the Reasonableness standard correlated positively with nuisance settlements; Tellabs appears to have bolstered defendants in these circuits in refusing to pay nuisance settlements. In Model 1, the coefficient on Reasonableness is positive and significant at the $1 \%$ level; the coefficient on Reasonableness $x$ Post-Tellabs is negative significant at the $5 \%$ level. At the other end of the spectrum, the coefficient for the Preponderance standard is insignificant, as is the interaction variable with Post-Tellabs, suggesting that Tellabs had little effect on nuisance settlement in those circuits. When we 


\section{Supreme Court and Securities Class Actions}

isolate the Ninth Circuit in Model 2, we see no effect of Tellabs within the circuit standing alone. The coefficient on Post-Tellabs is not significantly different from zero. In Model 3, we observe that the coefficient on Ninth Circuit is negative and significant at the $5 \%$ levelindicating that prior to Tellabs, the Ninth Circuit had significantly lower probability of a nuisance suit outcome relative to the other circuits. In contrast, we find a positive coefficient (significant at the $5 \%$ level) on the interaction variable between the Ninth Circuit and Post-Tellabs. This suggests that Tellabs increased the likelihood of nuisance settlement in the Ninth Circuit. With dismissal less likely in the Ninth Circuit after Tellabs, defendants appear to have become more willing to settle weak cases for low value settlement amounts. ${ }^{37}$

\subsection{Tellabs and Dura}

One potentially confounding effect on our analysis of the impact of Tellabs on lower court decisionmaking is another Supreme Court decision affecting motions to dismiss, Dura Pharmaceuticals, Inc. v. Broudo. ${ }^{38}$ Dura had a fairly typical profile for a securities fraud class action: pharmaceutical company announces declining sales and the FDA's rejection of a new product, stock price falls, lawsuit ensues. What was unusual about Dura's fact pattern was the sequence of these events. The stock price fall came in response to the announcement of the decline in sales, while the FDA's failure to approve the new product came eight months later.

\footnotetext{
${ }^{37}$ As a robustness test, we added the Top Attorney and All Institutional Lead Plaintiff variables to assess the importance of attorney and lead plaintiff expertise (and selection) to the three models in Table 7. Unreported, the robustness models generate the same qualitative results as in Table 7.

We also re-estimate the models in Table 7 with a different cutoff for nuisance suits--treating settlements for $\$ 4$ million or less as a nuisance settlement. Unreported, models generated similar results as in Table 7 except that the coefficient on Reasonableness $x$ Post-Tellabs in Model 1 is significant at only the $10 \%$ level. The coefficient on Ninth Circuit in Model 3 is only significant at the $14.7 \%$ level and the coefficient on Ninth Circuit x Post-Tellabs is significant at the $16.6 \%$ level, beyond the limits of conventional significance.

${ }^{38} 544$ U.S. 336 (2005).
} 


\section{Supreme Court and Securities Class Actions}

This latter announcement was met by a drop in the stock price, but the price quickly rebounded. Given the rebound in the stock price shortly after the FDA announcement, the PSLRA's damages cap would likely have precluded the recovery of any damages if they were measured from by the reaction to that announcement. ${ }^{39}$ Thus, framing the class period to end with the announcement of the sales decline provided the maximum available value line, even though it meant a somewhat shorter class period to apply that value line to. Moreover, the FDA rejection gave the plaintiffs' lawyers another set of misstatements with which to satisfy the requisite Rule $10 \mathrm{~b}-5$ elements, in particular scienter and materiality.

In most circuits, the Dura plaintiffs' lawyers' stratagem would have been easily rebuffed by the court, as the majority view required some connection between the alleged misstatement and the economic loss claimed. ${ }^{40}$ The district court in Dura agreed, dismissing the allegation relating to the FDA rejection for failure to plead loss causation. Importantly, the district court also rejected the allegations relating to the sales decline for failure to adequately plead scienter. The Ninth Circuit, however, reversed the dismissal of the FDA allegations, holding that the plaintiff's loss only need "touch" the misstatement (Touch Causation), and that this requirement could be satisfied by alleging that the price was inflated by the misrepresentation at the time of purchase. ${ }^{41}$

The Supreme Court, in a unanimous, opinion, rejected the Ninth Circuit's touch causation standard as inconsistent with the PSLRA's requirement that the plaintiff show that

\footnotetext{
${ }^{39}$ Exchange Act $\S 21 \mathrm{D}(\mathrm{e}), 15$ U.S.C. 78u-4(e).

${ }^{40}$ Emergent Capital Inv. Management, LLC v. Stonepath Group, Inc., 343 F.3d 189 (2nd Cir. 2003); Semerenko v. Cendant Corp., 223 F.3d 165 (3rd Cir. 2000); Miller v. Asensio \& Co., Inc., 364 F.3d 223 (4th Cir. 2004); Nathensen v. Zonagen, Inc., 267 F.3d 400 (5 ${ }^{\text {th }}$ Cir. 2001); Caremark, Inc. v. Coram Healthcare Corp., 113 F.3d 645 (7th Cir. 1997); Robbins v. Koger Properties, Inc., 116 F.3d 1441 (11th Cir. 1997).

${ }^{41}$ Broudo v. Dura Pharmaceuticals, Inc., 339 F.3d 933 (9th Cir. 2003).
} 


\section{Supreme Court and Securities Class Actions}

the misstatement "caused" the loss. ${ }^{42}$ The Court went on to hold that plaintiffs must also plead some basis for loss causation in their complaint, without specifying exactly what that might entail. Given the general consensus on the issue of loss causation prior to the Supreme Court's decision in Dura, the Ninth Circuit's position was something of an outlier, shared only by the Eighth Circuit. ${ }^{43}$ Thus, we predict the decision had little effect on practice in securities class actions.

Unfortunately, our sample is not designed to test the influence of Dura on dismissal decisions. We have very few loss causation decisions in the Ninth Circuit prior to the Supreme Court's Dura decision, perhaps because the "touch causation" standard made filing a motion to dismiss on such grounds futile. So instead of looking at motion to dismiss decisions, we collect the number of words that plaintiffs' attorneys include in their complaints addressing loss causation and use it as dependent variable in an ordinary least squares regression. For the independent variables, we include an indicator variable for decisions Post-Dura, another, Touch Causation, for cases in those circuits which did not require proof of loss causation prior to Dura (the Eighth and Ninth Circuits), and an interaction variable between those two to capture the effect of the change in the law in those circuits represented by Dura. In addition, we include the Case Control variables.

$$
\begin{aligned}
& \text { Loss Causation } \text { Words }_{\mathrm{i}}=\alpha+\beta_{1 \mathrm{i}} \text { Post } \text { Dura }_{\mathrm{i}}+\beta_{2 \mathrm{i}} \text { Touch Causation }_{\mathrm{i}} \\
& +\beta_{3 \mathrm{i}} \text { Touch Causation*Post-Dura }_{\mathrm{i}}+\sum \beta_{\mathrm{ki}} \text { Case Controls }_{\mathrm{ki}}+\varepsilon_{\mathrm{i}}
\end{aligned}
$$

\footnotetext{
${ }^{42}$ Exchange Act § 21D(b)(4); 15 U.S.C. 78u-4(b)(4) (plaintiff must show that "the [challenged] act or omission of the defendant $* * *$ caused the loss for which the plaintiff seeks to recover damages.").

${ }^{43}$ In re Control Data Corp. Sec. Litig., 933 F.2d 616 (8th Cir. 1991).
} 


\section{Supreme Court and Securities Class Actions}

Table 8 presents the results. In Model 1, note that the coefficient on Touch Causation is negative and significant at the $5 \%$ level; however, the coefficient on Touch Causation $x$ PostDura is positive and significant at the $5 \%$ level. While Touch Causation jurisdiction had significantly shorter loss causation sections prior to Dura (as predicted because those jurisdictions did not require proof of loss causation), post-Dura plaintiffs increased the length of their loss causation sections in Touch Causation circuits up to approximately the same length as in the non-Touch Causation jurisdictions. This increase occurred particularly in the Ninth Circuit. The coefficient on Post-Dura in Model 2 (Ninth Circuit only) is positive and significant at the $5 \%$ level. In Model 3, the coefficient on Ninth Circuit is negative and significant at the $5 \%$ level while the Ninth Circuit $x$ Post-Dura interaction term is positive and significant at the 5\% level. Thus, we conclude that Dura's primary impact was on pleading practices in the Ninth Circuit. $^{44}$

[Insert Table 8 About Here].

\section{Conclusion}

This study examines the impact of the Supreme Court's first decision interpreting the "strong inference" pleading standard of the PSLRA. In Tellabs, the Supreme Court rejected the Seventh Circuit's "reasonableness" standard for drawing inferences of fraudulent intent from a

\footnotetext{
${ }^{44}$ As a robustness test, we substitute the log of words as the dependent variable in the models in Table 8. Not reported, the robustness models provided similar results. The coefficient on Post-Dura is positive and significant at the $1 \%$ level in all three models, indicating an increase in the length of the loss causation section for all circuits post-Dura. In Model 3, the coefficient on Ninth Circuit is negative and significant at the $5 \%$ level while the Ninth Circuit x Post-Dura interaction term is positive and significant at the $5 \%$ level. Unlike the models in Table 8 , however, the coefficient on Touch Causation and Touch Causation $x$ Post-Dura are not significantly different from zero-indicating that in the robustness regressions the effect of Dura on the loss causation section length is greatest primarily for the Ninth Circuit.
} 


\section{Supreme Court and Securities Class Actions}

complaint. The Seventh Circuit standard was consistent with longstanding practice in the federal courts, but difficult to square with the language adopted by Congress in the PSLRA. Consequently, the reasonableness standard was a distinct outlier among the circuit courts, and the Supreme Court's reversal of it had little impact.

Substantially more important was the Tellabs Court's rejection of the "preponderance" standard followed in the First, Fourth, Sixth and Ninth Circuits. We find that circuits that employed a preponderance standard prior to Tellabs, particularly the Ninth Circuit, are less likely to dismiss on scienter grounds after that decision. We also find that Tellabs correlates with an overall lower likelihood of dismissal in the Ninth Circuit. The result of this reduction in the standards for pleading fraud in the Ninth Circuit means that defendants are more willing to pay a nuisance settlement post-Tellabs. These findings suggest that Tellabs may have been, on balance, a victory for the plaintiffs' bar, despite its reversal of a pro-plaintiff decision in the lower court. 


\section{Supreme Court and Securities Class Actions}

Table 1: Sample Description Panel A

\begin{tabular}{lcc}
\hline Year of Suit Filing & Freq. & Percent \\
2003 & 147 & 26.16 \\
2004 & 174 & 30.96 \\
2005 & 140 & 24.91 \\
2006 & 87 & 15.48 \\
2007 & 14 & 2.49 \\
Total & 562 & 100 \\
\hline & & \\
\hline Circuit Court & Freq. & Percent \\
1 & 37 & 6.58 \\
2 & 102 & 18.15 \\
3 & 48 & 8.54 \\
4 & 21 & 3.74 \\
5 & 50 & 8.9 \\
6 & 25 & 4.45 \\
7 & 26 & 4.63 \\
8 & 26 & 4.63 \\
9 & 149 & 26.51 \\
10 & 23 & 4.09 \\
11 & 52 & 9.25 \\
12 & 3 & 0.53 \\
Total & 562 & 100 \\
\hline & &
\end{tabular}

Panel B

\begin{tabular}{lcccccc}
\hline & \multicolumn{2}{c}{ All } & \multicolumn{2}{c}{$\mathbf{9}^{\text {th }}$ Cir. } & \multicolumn{2}{c}{ Other } \\
\hline Suit Outcome (If Known) & Freq. & Percent & Freq. & Percent & Freq. & Percent \\
Settlement & 185 & 47.44 & 45 & 41.67 & 140 & 49.65 \\
Trial Verdict for Plaintiff & 1 & 0.26 & 1 & 0.93 & 0 & 0.00 \\
Summary Judgment for Defendant & 4 & 1.03 & 1 & 0.93 & 3 & 1.06 \\
Voluntary Dismissal & 45 & 11.54 & 17 & 15.74 & 28 & 9.93 \\
Dismissal with Prejudice & 155 & 39.74 & 44 & 40.74 & 111 & 39.36 \\
Total & 390 & 100 & 108 & 100.00 & 282 & 100.00 \\
\hline
\end{tabular}

Chi2 test of the difference between the $9^{\text {th }}$ Cir and Other $=5.9969(p r=0.199)$ 


\section{Supreme Court and Securities Class Actions}

Table 2: Summary Statistics for the Independent Variables

\begin{tabular}{|c|c|c|c|c|c|c|c|}
\hline \multirow[b]{2}{*}{ Variable } & \multicolumn{2}{|c|}{ All } & \multicolumn{2}{|c|}{$9^{\text {th }}$ Cir. } & \multicolumn{2}{|c|}{ Other } & \multirow{2}{*}{$\begin{array}{c}\begin{array}{c}\text { Tests of } \\
\text { Differences }\end{array} \\
\text { p-value }\end{array}$} \\
\hline & Mean & $\begin{array}{l}\text { Stand. } \\
\text { Dev. }\end{array}$ & Mean & $\begin{array}{c}\text { Stand. } \\
\text { Dev. }\end{array}$ & Mean & $\begin{array}{c}\text { Stand. } \\
\text { Dev. }\end{array}$ & \\
\hline Section 11 & 0.110 & 0.313 & 0.075 & 0.265 & 0.126 & 0.332 & 0.067 \\
\hline Section 14 & 0.029 & 0.167 & 0.043 & 0.203 & 0.022 & 0.147 & 0.151 \\
\hline Govt. Investigation & 0.269 & 0.444 & 0.228 & 0.420 & 0.288 & 0.453 & 0.120 \\
\hline Restatement & 0.364 & 0.482 & 0.370 & 0.484 & 0.361 & 0.481 & 0.835 \\
\hline Officer Term. & 0.322 & 0.468 & 0.296 & 0.458 & 0.334 & 0.472 & 0.357 \\
\hline Auditor Term. & 0.069 & 0.253 & 0.082 & 0.276 & 0.063 & 0.243 & 0.384 \\
\hline Market Capitalization & 6.386 & 2.178 & 6.420 & 1.968 & 6.374 & 2.252 & 0.827 \\
\hline High Tech & 0.156 & 0.363 & 0.201 & 0.402 & 0.136 & 0.343 & 0.040 \\
\hline FDA & 0.037 & 0.190 & 0.022 & 0.147 & 0.044 & 0.206 & 0.189 \\
\hline Confidential & 0.5241 & 0.500 & 0.478 & 0.501 & 0.545 & 0.499 & 0.134 \\
\hline Insider Trading & 0.576 & 0.495 & 0.586 & 0.494 & 0.571 & 0.496 & 0.739 \\
\hline Bonus & 0.291 & 0.455 & 0.249 & 0.433 & 0.310 & 0.463 & 0.126 \\
\hline Offering & 0.283 & 0.451 & 0.270 & 0.445 & 0.288 & 0.454 & 0.655 \\
\hline Acquisition & 0.140 & 0.348 & 0.119 & 0.325 & 0.150 & 0.358 & 0.310 \\
\hline Merger & 0.081 & 0.274 & 0.060 & 0.237 & 0.091 & 0.289 & 0.189 \\
\hline Top Attorney & 0.597 & 0.491 & 0.673 & 0.471 & 0.571 & 0.496 & 0.063 \\
\hline All Institutional Lead Plaintiff & 0.383 & 0.487 & 0.338 & 0.475 & 0.338 & 0.475 & 0.211 \\
\hline
\end{tabular}

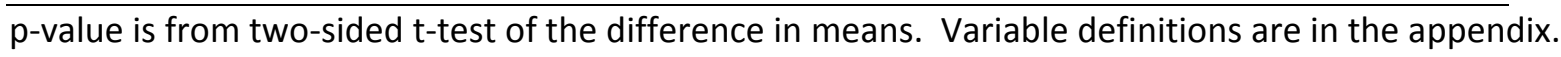




\section{Supreme Court and Securities Class Actions}

Table 3: Basis for Dismissal

\begin{tabular}{|c|c|c|c|c|}
\hline $\begin{array}{l}\text { Final Dismissal Decision } \\
\text { Grounds }\end{array}$ & $\begin{array}{l}\text { Dismissal } \\
\text { denied based } \\
\text { on the ground } \\
(=-1)\end{array}$ & $\begin{array}{l}\text { Did not rule on the } \\
\text { ground or both } \\
\text { denied and granted } \\
\text { dismissal based on } \\
\text { the ground }(=0)\end{array}$ & $\begin{array}{l}\text { Dismissal } \\
\text { granted (at } \\
\text { least partially) } \\
\text { based on the } \\
\text { ground (=1) }\end{array}$ & Total \\
\hline \multirow[t]{2}{*}{ Scienter } & 91 & 144 & 156 & 391 \\
\hline & $23.27 \%$ & $36.83 \%$ & $39.9 \%$ & $100 \%$ \\
\hline \multirow[t]{2}{*}{ Loss Causation } & 54 & 297 & 40 & 391 \\
\hline & $13.81 \%$ & $75.96 \%$ & $10.23 \%$ & $100 \%$ \\
\hline \multirow[t]{2}{*}{ Forward Looking Safe Harbor } & 37 & 305 & 49 & 391 \\
\hline & $9.46 \%$ & $78.01 \%$ & $12.53 \%$ & $100 \%$ \\
\hline \multirow[t]{2}{*}{ Reliance } & 17 & 367 & 7 & 391 \\
\hline & $4.35 \%$ & $93.86 \%$ & $1.79 \%$ & $100 \%$ \\
\hline \multirow[t]{2}{*}{ Materiality } & 37 & 315 & 39 & 391 \\
\hline & $9.46 \%$ & $80.56 \%$ & $9.97 \%$ & $100 \%$ \\
\hline \multirow[t]{2}{*}{ Misstatement } & 67 & 226 & 98 & 391 \\
\hline & $17.14 \%$ & $57.8 \%$ & $25.06 \%$ & $100 \%$ \\
\hline \multirow[t]{2}{*}{ Puffery } & 12 & 366 & 13 & 391 \\
\hline & $3.07 \%$ & $93.61 \%$ & $3.32 \%$ & $100 \%$ \\
\hline \multirow[t]{2}{*}{ Attribution to Defendant } & 15 & 358 & 18 & 391 \\
\hline & $3.84 \%$ & $91.56 \%$ & $4.6 \%$ & $100 \%$ \\
\hline \multirow[t]{2}{*}{ Group Pleading } & 9 & 361 & 21 & 391 \\
\hline & $2.3 \%$ & $92.33 \%$ & $5.37 \%$ & $100 \%$ \\
\hline
\end{tabular}




\section{Supreme Court and Securities Class Actions}

Table 4: Suit Outcome

\begin{tabular}{|c|c|c|c|}
\hline & \multicolumn{3}{|c|}{ Terminate } \\
\hline & Model 1: All & Model 2: $9^{\text {th }}$ Cir. & Model 3: All \\
\hline \multirow[t]{2}{*}{ Post-Tellabs } & $-2.820^{* *}$ & $-3.755^{* *}$ & $-2.276^{* *}$ \\
\hline & $(-5.68)$ & $(-4.11)$ & $(-6.82)$ \\
\hline \multirow[t]{2}{*}{ Reasonableness } & 0.462 & & \\
\hline & $(1.07)$ & & \\
\hline \multirow[t]{2}{*}{ Reasonableness x Post-Tellabs } & 0.780 & & \\
\hline & $(0.84)$ & & \\
\hline \multirow[t]{2}{*}{ Preponderance } & 0.217 & & \\
\hline & $(0.75)$ & & \\
\hline \multirow[t]{2}{*}{ Preponderance x Post-Tellabs } & 0.703 & & \\
\hline & $(1.07)$ & & \\
\hline \multirow[t]{2}{*}{ Ninth Circuit } & & & 0.0312 \\
\hline & & & $(0.11)$ \\
\hline \multirow[t]{2}{*}{ Ninth Circuit x Post-Tellabs } & & & -0.874 \\
\hline & & & $(-1.03)$ \\
\hline \multirow[t]{2}{*}{ Section 11} & -0.615 & -1.789 & -0.601 \\
\hline & $(-1.45)$ & $(-1.41)$ & $(-1.43)$ \\
\hline \multirow[t]{2}{*}{ Section 14} & -1.094 & & -0.932 \\
\hline & $(-1.23)$ & & $(-1.03)$ \\
\hline \multirow[t]{2}{*}{ Govt. Investigation } & -0.298 & 0.113 & -0.286 \\
\hline & $(-1.00)$ & $(0.14)$ & $(-0.97)$ \\
\hline \multirow[t]{2}{*}{ Restatement } & $-0.592^{*}$ & $-2.620^{* *}$ & $-0.595^{*}$ \\
\hline & $(-2.23)$ & $(-3.87)$ & $(-2.24)$ \\
\hline \multirow[t]{2}{*}{ Officer Term. } & -0.437 & -0.247 & -0.420 \\
\hline & $(-1.61)$ & $(-0.39)$ & $(-1.55)$ \\
\hline \multirow[t]{2}{*}{ Auditor Term. } & -0.016 & 0.009 & -0.071 \\
\hline & $(-0.03)$ & $(0.01)$ & $(-0.14)$ \\
\hline \multirow[t]{2}{*}{ In(Market Capitalization) } & $0.238^{* *}$ & 0.049 & $0.235^{* *}$ \\
\hline & $(3.86)$ & $(0.31)$ & (3.91) \\
\hline \multirow[t]{2}{*}{ High Tech } & 0.034 & $1.834^{*}$ & 0.120 \\
\hline & $(0.11)$ & $(2.43)$ & $(0.37)$ \\
\hline \multirow[t]{2}{*}{ FDA } & -0.690 & -0.494 & -0.688 \\
\hline & $(-1.13)$ & $(-0.38)$ & $(-1.16)$ \\
\hline \multirow[t]{2}{*}{ Confidential } & -0.161 & -0.241 & -0.136 \\
\hline & $(-0.65)$ & $(-0.43)$ & $(-0.56)$ \\
\hline \multirow[t]{2}{*}{ Constant } & -0.574 & 0.975 & -0.444 \\
\hline & $(-1.33)$ & $(0.90)$ & $(-1.08)$ \\
\hline $\mathrm{N}$ & 414 & 112 & 414 \\
\hline pseudo $\mathrm{R}^{2}$ & 0.243 & 0.396 & 0.237 \\
\hline
\end{tabular}




\section{Supreme Court and Securities Class Actions}

$t$ statistics in parentheses; ${ }^{+} p<0.10,{ }^{*} p<0.05,{ }^{* *} p<0.01$. Logit model: Dependent variable "Terminate" equals 1 if suit ended in summary judgment for defendant, voluntary dismissal, or dismissal with prejudice; 0 if suit ended in either settlement or trial verdict for plaintiffs. Variable definitions are in the appendix. 


\section{Supreme Court and Securities Class Actions}

Table 5: Final Dismissal Decisions Based on Scienter

\begin{tabular}{|c|c|c|c|}
\hline & \multicolumn{3}{|c|}{ Scienter } \\
\hline & Model 1: All & Model 2: $9^{\text {th }}$ Cir. & Model 3: All \\
\hline \multirow[t]{2}{*}{ Post-Tellabs } & -0.114 & $-1.965^{*}$ & -0.0440 \\
\hline & $(-0.26)$ & $(-2.56)$ & $(-0.13)$ \\
\hline \multirow{2}{*}{ Reasonableness } & 0.0783 & & \\
\hline & $(0.18)$ & & \\
\hline \multicolumn{4}{|l|}{1} \\
\hline \multirow[t]{2}{*}{ Reasonableness x Post-Tellabs } & 1.398 & & \\
\hline & $(1.35)$ & & \\
\hline \multirow[t]{2}{*}{ Preponderance } & $0.878^{*}$ & & \\
\hline & $(2.48)$ & & \\
\hline \multirow[t]{2}{*}{ Preponderance $\mathrm{x}$ Post-Tellabs } & $-1.168^{+}$ & & \\
\hline & $(-1.86)$ & & \\
\hline \multirow[t]{2}{*}{ Ninth Circuit } & & & $1.343^{* *}$ \\
\hline & & & $(3.27)$ \\
\hline \multirow[t]{2}{*}{ Ninth Circuit x Post-Tellabs } & & & $-1.735^{*}$ \\
\hline & & & $(-2.57)$ \\
\hline \multirow[t]{2}{*}{ Insider Trading } & 0.134 & 0.258 & 0.159 \\
\hline & $(0.48)$ & $(0.35)$ & $(0.57)$ \\
\hline \multirow[t]{2}{*}{ Bonus } & 0.025 & 0.088 & 0.073 \\
\hline & $(0.08)$ & $(0.11)$ & $(0.24)$ \\
\hline \multirow[t]{2}{*}{ Offering } & -0.273 & -0.433 & -0.199 \\
\hline & $(-0.87)$ & $(-0.55)$ & $(-0.65)$ \\
\hline \multirow[t]{2}{*}{ Acquisition } & -0.102 & -0.893 & -0.038 \\
\hline & $(-0.31)$ & $(-1.07)$ & $(-0.11)$ \\
\hline \multirow[t]{2}{*}{ Merger } & -0.0888 & $2.444^{+}$ & -0.074 \\
\hline & $(-0.18)$ & $(1.77)$ & $(-0.16)$ \\
\hline \multirow[t]{2}{*}{ Constant 1} & 0.035 & $-4.694^{* *}$ & -0.023 \\
\hline & $(0.07)$ & $(-3.01)$ & $(-0.05)$ \\
\hline \multirow[t]{2}{*}{ Constant 1} & 0.574 & $-3.615^{*}$ & 0.518 \\
\hline & $(1.12)$ & $(-2.41)$ & $(1.04)$ \\
\hline Case Controls & Yes & Yes & Yes \\
\hline $\mathrm{N}$ & 251 & 70 & 251 \\
\hline pseudo $\mathrm{R}^{2}$ & 0.069 & 0.258 & 0.073 \\
\hline
\end{tabular}

$t$ statistics in parentheses; ${ }^{+} p<0.10,{ }^{*} p<0.05,{ }^{* *} p<0.01$. Ordered Logit Model: Dependent variable "Scienter" is defined to equal 1 if the final motion to dismiss decision ordered dismissal (at least partially) based on a failure to plead scienter with particularity, 0 if the decision either did not rule on dismissal based on scienter or both denied and granted dismissal based on scienter, and -1 if the decision denied dismissal based on scienter. Case Controls include Section 11, Section 14, Govt. Investigation, Restatement, Officer Term., Auditor Term., In(Market Capitalization), High Tech, FDA, Confidential, and Top Atty. Variable definitions are in the Appendix. 


\section{Supreme Court and Securities Class Actions}

Table 6: Number of Dismissal Decisions Before Final Dismissal

\begin{tabular}{|c|c|c|c|}
\hline & \multicolumn{3}{|c|}{ Number of Dismissal Decisions } \\
\hline & Model 1: AllI & Model 2: $9^{\text {th }}$ Cir. & Model 3: All \\
\hline Post-Tellabs & $\begin{array}{l}0.799 \\
(0.50) \\
\end{array}$ & $\begin{array}{c}6.556^{* *} \\
(2.80)\end{array}$ & $\begin{array}{l}0.339 \\
(0.30) \\
\end{array}$ \\
\hline Reasonableness & $\begin{array}{l}2.207^{*} \\
(2.29)\end{array}$ & & \\
\hline Reasonableness x Post-Tellabs & $\begin{array}{l}-0.791 \\
(-0.36) \\
\end{array}$ & & \\
\hline Preponderance & $\begin{array}{l}1.966^{*} \\
(2.29) \\
\end{array}$ & & \\
\hline Preponderance x Post-Tellabs & $\begin{array}{l}1.058 \\
(0.57) \\
\end{array}$ & & \\
\hline Ninth Circuit & & & $\begin{array}{l}2.908^{* *} \\
(3.34)\end{array}$ \\
\hline Ninth Circuit x Post-Tellabs & & & $\begin{array}{l}4.054^{*} \\
(2.11) \\
\end{array}$ \\
\hline Constant 1 & $\begin{array}{l}4.078^{* *} \\
(2.95) \\
\end{array}$ & $\begin{array}{l}6.507^{+} \\
(1.83) \\
\end{array}$ & $\begin{array}{l}4.039^{* *} \\
(2.85)\end{array}$ \\
\hline Constant 2 & $\begin{array}{l}6.608^{* *} \\
(4.34)\end{array}$ & $\begin{array}{l}10.60^{* *} \\
(2.60)\end{array}$ & $\begin{array}{l}7.265^{* *} \\
(4.38)\end{array}$ \\
\hline Constant 3 & $\begin{array}{l}8.199^{* *} \\
(4.60) \\
\end{array}$ & $\begin{array}{l}13.74^{* *} \\
(2.80) \\
\end{array}$ & $\begin{array}{l}9.862^{* *} \\
(4.24) \\
\end{array}$ \\
\hline Case Controls & Yes & Yes & Yes \\
\hline Motive Variables & Yes & Yes & Yes \\
\hline $\begin{array}{l}N \\
\text { pseudo } R^{2}\end{array}$ & $\begin{array}{c}134 \\
0.247 \\
\end{array}$ & $\begin{array}{c}40 \\
0.518 \\
\end{array}$ & $\begin{array}{c}134 \\
0.363\end{array}$ \\
\hline
\end{tabular}

$t$ statistics in parentheses; ${ }^{+} p<0.10,{ }^{*} p<0.05,{ }^{* *} p<0.01$. Ordered Logit Model: Dependent variable "Number of Dismissal Decisions" equals the number of opinions on motions to dismiss for cases that ultimately end with a dismissal with prejudice. The ordered logit models are estimated solely for class actions that resulted in a dismissal with prejudice. Case Controls include Section 11, Section 14, FDA, Insider Trading, Govt. Investigation, Restatement, Officer Term., Auditor Term., High Tech, Bonus, Offering, Acquisition, Merger, and Confidential. Motive Variables include Insider Trading, Bonus, Offering, Acquisition, and Merger. Variable definitions are in the Appendix 


\section{Supreme Court and Securities Class Actions}

Table 7 : Nuisance Suit Outcome

\begin{tabular}{|c|c|c|c|}
\hline & & Nuisance & \\
\hline & $\begin{array}{c}\text { Model } 1 \\
\text { All }\end{array}$ & $\begin{array}{l}\text { Model } 2 \\
9^{\text {th }} \text { Cir. }\end{array}$ & $\begin{array}{c}\text { Model } 3 \\
\text { All }\end{array}$ \\
\hline Post-Tellabs & $\begin{array}{l}-0.325 \\
(-0.60)\end{array}$ & $\begin{array}{l}0.336 \\
(0.32)\end{array}$ & $\begin{array}{l}-1.082^{*} \\
(-2.43)\end{array}$ \\
\hline Reasonableness & $\begin{array}{l}2.500^{* *} \\
(2.81)\end{array}$ & & \\
\hline Reasonableness x Post-Tellabs & $\begin{array}{l}-3.526^{*} \\
(-2.34)\end{array}$ & & \\
\hline Preponderance & $\begin{array}{l}-0.238 \\
(-0.46) \\
\end{array}$ & & \\
\hline Preponderance x Post-Tellabs & $\begin{array}{c}0.0868 \\
(0.10)\end{array}$ & & \\
\hline Ninth Circuit & & & $\begin{array}{l}-1.174^{*} \\
(-2.07) \\
\end{array}$ \\
\hline Ninth Circuit x Post-Tellabs & & & $\begin{array}{l}1.730^{+} \\
(1.88) \\
\end{array}$ \\
\hline Constant & $\begin{array}{c}-0.0651 \\
(-0.09)\end{array}$ & $\begin{array}{l}-3.160 \\
(-1.44)\end{array}$ & $\begin{array}{l}0.282 \\
(0.44) \\
\end{array}$ \\
\hline Case Controls & Yes & Yes & Yes \\
\hline $\begin{array}{l}N \\
\text { pseudo } R^{2}\end{array}$ & $\begin{array}{c}163 \\
0.134\end{array}$ & $\begin{array}{c}41 \\
0.224\end{array}$ & $\begin{array}{c}165 \\
0.088\end{array}$ \\
\hline
\end{tabular}

$t$ statistics in parentheses; ${ }^{+} p<0.10,{ }^{*} p<0.05,{ }^{* *} p<0.01$. Logit model: Dependent variable "Nuisance" is equal to 1 if the settlement amount was for \$3 million or less and 0 if the settlement amount was for greater than \$3 million. Models are estimated solely for class actions that resulted in settlement. Case Controls include Section 11 , Section 14, FDA, Insider Trading, Govt. Investigation, Restatement, Officer Term., Auditor Term., High Tech, Bonus, Offering, Acquisition, Merger, and Confidential. Motive Variables include Insider Trading, Bonus, Offering, Acquisition, and Merger. Variable definitions are in the appendix. 


\section{Supreme Court and Securities Class Actions}

Table 8: Loss Causation Words

\begin{tabular}{|c|c|c|c|}
\hline & \multicolumn{3}{|c|}{ Loss Causation Words } \\
\hline & $\begin{array}{c}\text { Model } 1 \\
\text { All }\end{array}$ & $\begin{array}{l}\text { Model } 2 \\
9^{\text {th }} \text { Cir. }\end{array}$ & $\begin{array}{c}\text { Model } 3 \\
\text { All }\end{array}$ \\
\hline Post-Dura & $\begin{array}{l}-166.9 \\
(-0.48)\end{array}$ & $\begin{array}{c}1028.5^{*} \\
(2.17)\end{array}$ & $\begin{array}{l}-77.99 \\
(-0.23)\end{array}$ \\
\hline Touch Causation & $\begin{array}{r}-1102.7^{*} \\
(-2.11) \\
\end{array}$ & & \\
\hline Touch Causation x Post-Dura & $\begin{array}{r}1303.1^{*} \\
(2.23)\end{array}$ & & \\
\hline Ninth Circuit & & & $\begin{array}{r}-1155.1^{*} \\
(-2.08)\end{array}$ \\
\hline Ninth Circuit x Post-Dura & & & $\begin{array}{c}1318.2^{*} \\
(2.11) \\
\end{array}$ \\
\hline Constant & $\begin{array}{r}1005.2^{*} \\
(2.04)\end{array}$ & $\begin{array}{l}-326.0 \\
(-0.34)\end{array}$ & $\begin{array}{l}958.4^{*} \\
(1.97)\end{array}$ \\
\hline Case Controls & Yes & Yes & Yes \\
\hline $\begin{array}{l}N \\
R^{2}\end{array}$ & $\begin{array}{c}340 \\
0.080\end{array}$ & $\begin{array}{c}90 \\
0.129\end{array}$ & $\begin{array}{c}340 \\
0.079\end{array}$ \\
\hline
\end{tabular}

$t$ statistics in parentheses; ${ }^{+} p<0.10,{ }^{*} p<0.05,{ }^{* *} p<0.01$. Ordinary Least Squares: Dependent variable "Loss Causation Words" is the number of words used to plead loss causation in the complaint. Case Controls include Section 11, Section 14, FDA, Insider Trading, Govt. Investigation, Restatement, Officer Term., Auditor Term., High Tech, Bonus, Offering, Acquisition, Merger, and Confidential. Variable definitions are in the appendix. 


\section{Supreme Court and Securities Class Actions}

\section{Appendix: Variable Definitions}

\section{Dependent Variables}

\begin{tabular}{|c|c|}
\hline Variable & Description \\
\hline Terminate & $\begin{array}{l}\text { Indicator variable equal to } 1 \text { if the class action ended in a summary judgment for } \\
\text { the defendant, a voluntary dismissal, or a dismissal with prejudice and } 0 \text { if the } \\
\text { class action ended in either a settlement or a victory at trial for the plaintiffs. }\end{array}$ \\
\hline Scienter & $\begin{array}{l}\text { Variable for the final motion to dismiss decision based on scienter pleading } \\
\text { grounds. Defined as equal to } 1 \text { if the final motion to dismiss decision ordered } \\
\text { dismissal (at least partially) based on the ground in question, } 0 \text { if the decision } \\
\text { either did not rule on dismissal based on the ground in question or both denied } \\
\text { and granted dismissal based on the ground in question, and -1 if the decision } \\
\text { denied dismissal based on the ground in question. }\end{array}$ \\
\hline Number of Dismissal Decisions & $\begin{array}{l}\text { The number of judge opinions on motions to dismiss for cases that ultimately } \\
\text { end with a dismissal with prejudice. }\end{array}$ \\
\hline Nuisance & $\begin{array}{l}\text { Indicator variable equal to } 1 \text { if the settlement amount was for } \$ 3 \text { million or less } \\
\text { and } 0 \text { if the settlement amount was for greater than } \$ 3 \text { million. }\end{array}$ \\
\hline
\end{tabular}

\section{Independent Variables}

\begin{tabular}{|c|c|}
\hline Case Control Variables & Description \\
\hline Section 11 & $\begin{array}{l}\text { Indicator variable equal to } 1 \text { if the complaint for a particular class action alleged } \\
\text { a Section } 11 \text { of the Securities Act of } 1933 \text { violation and } 0 \text { otherwise. }\end{array}$ \\
\hline Section 14 & $\begin{array}{l}\text { Indicator variable equal to } 1 \text { if the complaint for a particular class action alleged } \\
\text { a Section } 14 \text { of the Securities Exchange Act of } 1934 \text { violation and } 0 \text { otherwise. }\end{array}$ \\
\hline Govt. Investigation & $\begin{array}{l}\text { Indicator variable equal to } 1 \text { if the complaint indicated the presence of a SEC or } \\
\text { other governmental investigation or enforcement action relating to the fraud at } \\
\text { issue and } 0 \text { otherwise. }\end{array}$ \\
\hline Restatement & $\begin{array}{l}\text { Indicator variable equal to } 1 \text { if the complaint indicated that the company } \\
\text { announced a restatement covering at least part of the class period and } 0 \\
\text { otherwise. }\end{array}$ \\
\hline Officer Term. & $\begin{array}{l}\text { Indicator variable equal to } 1 \text { if the complaint indicated that a top officer of the } \\
\text { defendant company resigned or was terminated during the class period and } 0 \\
\text { otherwise. }\end{array}$ \\
\hline Auditor Term. & $\begin{array}{l}\text { Indicator variable equal to } 1 \text { if the complaint indicated that the auditor resigned } \\
\text { or was terminated during the class period and } 0 \text { otherwise. }\end{array}$ \\
\hline High Tech & $\begin{array}{l}\text { Indicator variable equal to } 1 \text { if the firm is in SIC codes } 3570-3577 \text { or } 7370-7379 \\
\text { and } 0 \text { otherwise }\end{array}$ \\
\hline FDA & $\begin{array}{l}\text { Indicator variable equal to } 1 \text { if the complaint for a particular class action is } \\
\text { related to disclosures relating to the Federal Drug Administration and } 0 \\
\text { otherwise. }\end{array}$ \\
\hline
\end{tabular}




\section{Supreme Court and Securities Class Actions}

Confidential

Market Capitalization

Top Attorney

All Institutional Lead Plaintiff
Indicator variable equal to 1 if the first complaint filed after the selection of the lead plaintiff refers to at least one confidential witness who was an employee of the issuer and 0 otherwise.

Market value of a company's common equity (in \$ millions) at the end of the fiscal year preceding the beginning of the class period

Indicator variable equal to 1 if the appointed lead counsel is one of the top attorney firms (measured by frequency of appointment as lead counsel) in the Choi (2009) dataset.

Indicator variable equal to 1 if the appointed lead plaintiff consists solely of institutional lead plaintiffs in the Choi (2009) dataset. 